\title{
Correlated glomerular convergence and latency coding of odors in mitral cells
}

\author{
Detlev Schild \\ From 1st International Workshop on Odor Spaces \\ Hannover, Germany. 4-7 September 2013
}

Behavioral responses to olfactory stimuli can happen after less than half a second after stimulus arrival. Given ORN spike rates in the order of 0 to 15 spikes/s it appears unlikely that average spike rates play a major role for the detection of the odor and the bahavioral response to it. We therefore assumed the other extreme, i.e. that the first spike of an odor response of a mitral cells is important for detection and quality coding (which does not exclude other effects). Using activity contrast imaging (ACI, [1]) we could indeed show that the response latency vectors code odor quality with high fidelity [2] in virtually synchronous ensembles of mitral cells [3]. We hypothesize that the first spike of a mitral cell is somehow induced by correlated glomerular input. This view is strengthened by the existence of bifurcations in ORN axons so far seen in Xenopus [4] and mice [5]. Such bifurcations obviously lead to hardwired correlations in an ontogenetical situation where, due to a relatively low number of axons, stimulus-induced, correlated ORN activities are sparse or absent.

Published: 16 April 2014

\section{References}

1. Junek S, Chen T-W, Alevra M, Schild D: Activity correlation imaging: visualizing function and structure of neuronal populations. Biophys $J$ 2009, 96:3801-3809.

2. Junek S, Kludt E, Wolf F, Schild D: Olfactory coding with patterns of response latencies. Neuron 2010, 67:872-884.

3. Chen T-W, Lin B-J, Schild D: Odor coding by modules of coherent mitral/ tufted cells in the vertebrate olfactory bulb. Proc Natl Acad Sci U S A 2009, 106:2401-2406.

4. Nezlin LP, Schild D: Individual olfactory sensory neurons project into more than one glomerulus in Xenopus laevis tadpole olfactory bulb. J Comp Neurol 2005, 481:233-239.

5. Marcucci F, Maier-Balough E, Zou D-J, Firestein S: Exuberant growth and synapse formation of olfactory sensory neuron axonal arborizations. J Comp Neurol 2011, 519:3713-3726.

University of Göttingen, Germany

(0) 2014 Schild; licensee BioMed Central Ltd. This is an Open Access article distributed under the terms of the Creative Commons Attribution License (http://creativecommons.org/licenses/by/2.0), which permits unrestricted use, distribution, and reproduction in any medium, provided the original work is properly cited. The Creative Commons Public Domain Dedication waiver (http:// creativecommons.org/publicdomain/zero/1.0/) applies to the data made available in this article, unless otherwise stated.
doi:10.1186/2044-7248-3-S1-012
Cite this article as: Schild: Correlated glomerular convergence and latency coding of odors in mitral cells. Flavour 2014 3(Suppl 1):012.

Submit your next manuscript to BioMed Central and take full advantage of:

- Convenient online submission

- No space constraints or color figure charges

- Immediate publication on acceptance

- Inclusion in PubMed, CAS, Scopus and Google Scholar

- Research which is freely available for redistribution
- Thorough peer review 